\title{
Effects of counter-ions on the electropolymerization behaviors and properties of polyaniline
}

\author{
Han Xu*, Xiaonan $W u$ \\ Department of Chemical Engineering, Chengde Petroleum College \\ Chengde 067000, Hebei, P. R. China \\ *E-mail: cdpc_xuh@163.com
}

Received: 16 August 2021 / Accepted: 25 September 2021 / Published: 10 November 2021

\begin{abstract}
Conductive polymer of polyaniline (PANI) was prepared by potentiostatic electropolymerization technique onto $\mathrm{Au}$ at $25^{\circ} \mathrm{C}$ in a series of solutions containing $\mathrm{NO}_{3}^{-}, \mathrm{SO}_{4}{ }^{2-}, \mathrm{Cl}^{-}, \mathrm{ClO}_{4}{ }^{-}$and $\mathrm{PO}_{4}{ }^{3-}$, respectively. The effects of different counter-ions on the electropolymerization behaviors and capacitive behaviors of PANI films were investigated by cyclic voltammetry (CV) and electrochemical impedance spectroscopy (EIS) electrochemical measurements. As a result, the difficulty of electropolymerization of aniline in electrolytes containing different kinds of counter-ions from high to low is in the order: $\mathrm{NO}_{3}{ }^{-}>\mathrm{SO}_{4}{ }^{2-}>\mathrm{ClO}_{4}{ }^{-}>\mathrm{Cl}^{-}>\mathrm{PO}_{4}{ }^{3-}$, while the rate of electropolymerization of aniline in electrolytes containing different kinds of counter-ions from high to low is in the order: $\mathrm{SO}_{4}{ }^{2-}>\mathrm{NO}_{3}{ }^{-}>\mathrm{Cl}^{-}>\mathrm{ClO}_{4}{ }^{-}>$ $\mathrm{PO}_{4}{ }^{3-}$. The order of the conductivity of $\mathrm{pAn}$ films obtained in solutions containing different counter-ions from high to low is: $\mathrm{PANI} / \mathrm{HNO}_{3}>\mathrm{PANI} / \mathrm{H}_{2} \mathrm{SO}_{4}>\mathrm{PANI} / \mathrm{HCl}>\mathrm{PANI} / \mathrm{HClO}_{4}>\mathrm{PANI} / \mathrm{H}_{3} \mathrm{PO}_{4}$. The order of the charge storage ability of PANI obtained in different solutions from high to low is: $\mathrm{PANI} / \mathrm{H}_{2} \mathrm{SO}_{4}>$ $\mathrm{PANI} / \mathrm{HNO}_{3}>\mathrm{PANI} / \mathrm{HCl}>\mathrm{PANI} / \mathrm{HClO}_{4}>\mathrm{PANI} / \mathrm{H}_{3} \mathrm{PO}_{4}$.
\end{abstract}

Keywords: polyaniline; electropolymerization; counter-ions; EIS; capacitive behaviors.

\section{FULL TEXT}

(C) 2021 The Authors. Published by ESG (www.electrochemsci.org). This article is an open access article distributed under the terms and conditions of the Creative Commons Attribution license (http://creativecommons.org/licenses/by/4.0/). 